\title{
Geskiedsfilosofie in 'n krisis: Die noodwendigheid en aktualiteit van die nasionale staatsidee
}

MJ Schoeman

\begin{abstract}
Philosophy of history in crisis: The actuality and necessity of the concept of the national state
\end{abstract}

The aim of this essay is to explicate the thesis of an intrinsic relationship between the Enlightenment philosophy of history and the (ideological) war amongst world citizens in which we are entangled today. This is explained in terms of certain 'deficiencies' (philosophical, theological, political and historical) inherent in the Enlightenment view of history. It is argued that a truly modern approach to history (as opposed to the antimodern, eschatological and moralistic view of the Enlightenment) should take its bearing from the idea of the nation, thereby acknowledging the rise of a global network of national states as one of the most remarkable features of our age.

Ek gaan uit van 'n standpunt wat reeds implisiet by Sokrates en Plato, en eksplisiet by Aristoteles teenwoordig is, en dit is naamlik dat filosofie primêr politieke filosofie is. Die filosofie is deel van die mens se lewenspraxis wat hom altyd voltrek binne die raamwerk van wat eenmaal genoem is die 'polis', en wat ons vandag breedweg kan bestempel as die politieke proses waardeur mense in staatlike en interstaatlike verband poog om iets van die goeie lewe (the good life) te verwerklik. Die filosofie reflekteer hierdie politieke praxis, en wel op so ' $n$ wyse dat dit wat implisiet daarin vervat is, eksplisiet aan die orde gestel word. Die opheldering (Aufklärung) wat hierdeur meegebring word, is daarby 'n kritiese opheldering in dié sin dat dit nie bloot ' $n$ artikulasie is van wat is nie, maar tegelyk ook van wat behoort te wees. Geen filosofie is sy sout werd as dit nié sy vinger kan lê op die onderliggende probleme van sy tyd nie. Probleme is daar immers altyd - selfs al het die meeste mense nie die geringste vermoede daaromtrent nie. Die filosoof moet 'n fyn aanvoeling openbaar vir die impasses of naderende krisisse waarin die menslike lewenspraxis momenteel verstrengel raak, en in sy verwoording daarvan moet hy tegelykertyd die uitkomkanse aandui wat daar inherent aan die krisissituasie is. En dit alles natuurlik sonder 
enige pretensie as sou die aangeduide weg die finale oplossing vir alle tye en vir alle probleme bied. Odo Marquard skryf iewers dat die filosofie (hy noem dit hermeneutiek) die kuns is om jouself op ' $n$ elegante wyse te verskoon van die werklikheid en die onmiddellike impak wat dit op jou het. Merleau-Ponty noem die filosofie 'die luukse van ' $n$ besit op ' $n$ afstand' (in sy Éloge de la philosophie). Die sogenaamde radikaliteit van die wysgerige denke omskryf hy soos volg: 'Radikaliteit is die hardnekkige weiering om enige oplossing vir ' $n$ probleem te aanvaar wat daardie probleem finaal verstik.'

Tot sover dan wat betref die aard van die filosofiese denke. Vervolgens wil ek uitkom by die tema wat vir behandeling in vooruitsig gestel is, en hierin is daar allereers sprake van die geskiedsfilosofie. En nou wil ek die leser nie verveel met 'n historiese relaas oor die ontstaan van die geskiedsfilosofie en hoe dit deur sy verskillende eksponente heen ontwikkel het nie. Ek volstaan met 'n baie kort omskrywing van die begrip 'geskiedsfilosofie' en wat ek daaronder verstaan. Die leser sal merk dat ek in my siening van wat geskiedsfilosofie is, swaar op veral Odo Marquard (1973) leun, wat vir baie seker geen onbekende is nie. Ek persoonlik vind sterk aanklank by Marquard en by wat hy noem sy 'Schwierigkeiten mit der Geschichtsphilosophie'. Ek is dit veral eens met sy siening betreffende die politieke konsekwensies van die geskiedsfilosofie, en ek wil veral hierdie aspek verder uitbou. (Ek het immers vroeër gesê dat filosofie vir my primêr politieke filosofie is.) Ek het egter bedenkinge wat betref Marquard se 'Abschied' (afskeid) van die geskiedsfilosofie. Ek verkies om te praat van ' $n$ 'vernuwing' van die geskiedsfilosofie - miskien omdat ek meer met die politiek gepreokkupeerd is as Marquard. (Marquard se denke bied waardevolle vertrekpunte vir 'n politieke filosofie, maar hy het dit self nie positief verder ontwikkel nie. Sy 'skepsis' laat hom dit skynbaar nie toe nie.)

\section{I}

Die geskiedsfilosofie waarvan hier sprake is, is ' $n$ dateerbare fenomeen. Die geskiedsfilosofie wat homself uitdruklik só noem, het rondom die middel van die E18 sy opwagting gemaak (Marquard 1973: 67; Koselleck 1969). Dit is dus 'n produk van die Europese Aufklärung met sy universalistiese voorstellings van 'n wêreldburgerlike humaniteit. Die universaliteit wat hier in vooruitsig gestel is, was nie meer die universaliteit van die Kosmos en sy ewige Skepper nie - dit was 'n 
wêreldimmanente orde wat deur die mens self opgebou moes word.

Daar was vroeër reeds die Kerkhervorming. Dit het ' $n$ traumatiese uitwerking in Europa gehad. Die eenheid van die geloof is sigbaar verbreek. Die Christelike geloof het onvermydelik pluralisties geword, dit wil sê 'n saak van individuele beslissing. Vir die moderne mens het niks anders oorgebly as om die wêreld vanuit homself weer op te bou nie, en daarby moes hy tot die besef kom dat hy niks anders tot sy beskikking het nie as net homself en sy 'Wille zu sich selbst grundgebender Rationalität', soos wat Blumenberg (1966: 188) dit stel. Wat in die geloof verlore was, moes deur kennis weer bygebring word, en so het die universalistiese heilsekerheid oorgegaan in die geskiedsfilosofie van die Aufklärung.

Aufklärung definieer Kant in 1784 as 'der Ausgang des Menschen aus seiner selbstverschuldeten Unmündigkeit'. Wat hier van die Aufklä rung gesê word, word net so op die geskiedenis oorgedra. Vir die geskiedsfilosofie is die geskiedenis die toneel van vooruitgang, emansipasie en die bewerkstelliging van menslike outonomie. Dié siening kan 'n mens maklik nagaan by figure soos Voltaire, Turgot, Lessing, die denkers van die Franse Revolusie en Condorcet, vanwaar dit verder strek tot in die sogenaamde klassieke Duitse filosofie en uiteindelik die Marxisme.

Met die aanspraak op outonomie, vervul die mens geskiedsfilosofies die rol van subjek van die geskiedenis - 'n rol wat geskiedsteologies (d w s minstens vanaf Augustinus tot en met Bossuet) uitsluitlik vir God gereserveer is. Karl Löwith (1970) het ook daarop gewys dat die geskiedsfilosofie 'n surrogaat is vir die geskiedsteologie van weleer. (Ek vermy met opset die term 'sekularisasie'!) Die geskiedsteologie, met sy idee van ' $n$ universele 'heilsgeskiedenis', leef in 'n sekere sin voort in die geskiedsfilosofie. Die geskiedsfilosofie proklameer te midde van 'n veelheid van geskiedenisse 'die' geskiedenis in enkelvoud - die 'monomythos' (Marquard 1981: 99) van 'n onkeerbare wêreldhistoriese vooruitgang na vryheid in die medium van die revolusionêre emansipasie. Hierdie 'singularisering' van die geskiedenis (Koselleck) beteken die einde van die polimitiese veelvoud van geskiedenisse. Die mensdom durf hom nie langer individueel en multi-kultureel in afsonderlike geskiedenisse laat boekstaaf nie. Daar is maar een weg ('n smal weg) na ware humaniteit, en wie hom nie aan hierdie weg wil hou nie, word verklaar tot ketter, 'verraaier van die geskiedenis', 'vyand van die mensdom', of minstens 'reaksionêr'.

Dit is belangrik om hiér reeds in te sien dat die revolusionêre pro- 
gram van die Aufklärung hom uit die staanspoor laat dikteer het vanuit die raamwerk van 'n verlore geloof. Dit was dan ook des te meer die geval namate die Aufklärers te staan gekom het voor die steeds magtig voorhande werklikhede van die ou geloofspraktyke in die Kerk.

Maar die eintlike probleem van die geskiedsfilosofie was dat hy in die nuwe heilsekerheid wat hy gaan proklameer het, geen beroep op die gelowige aanname van 'n transendente openbaring kon doen nie. $\mathrm{Al}$ gou moes hy toesien hoe sy program van universaliteit omswaai in 'n program van betwisbaarheid. Hierdie feit is veral beklemtoon deur Reinhart Koselleck (1969) in sy grondige werk oor die samehang van 'aufgeklärte Kritik' en 'weltbürgerliche Krise'.

Enersyds het die geskiedsfilosofiese universalismes die karakter van 'n uit en uit noodwendige en apodiktiese oriënteringswete, soortgelyk aan die heilsekerheid van die Christelike geloof. As sodanig was die Aufklärung-idees (aangaande die mens, die wêreld, die toekoms en die weg daarheen) buitengewoon dinamies. Ook die vooruitgang wat op die gebied van die natuurwetenskap en die tegniek gemaak is, het groot stukrag aan hierdie idees verleen. Maar op die lange duur kon die burgerlike wêreld nie die feit miskyk nie dat sy eie idees (kragtens die beginsel van die twyfel wat hy sy eie gemaak het) net so aanvegbaar was as dié van die tradisie wat hy verwerp het. En daar dit vir die Aufklärung tegelykertyd ook gegaan het om 'n wêreldveranderende, reële handelingsoriëntering, was dit dan ook onvermydelik dat die kwessie van die aanvegbaarheid van idees op 'n fisiese geveg moes uitloop. Die geskiedsfilosofie van die Aufklärung het oorgegaan in 'n ideologiese wêreldburgeroorlog, 'n ontwikkeling wat in dieselfde jaar deur beide Koselleck en Hanno Kesting (1959) uitgewys is. Kesting trek hierdie ontwikkeling verder deur na die huidige Oos-Wes-konflik as die aktuele gestalte van 'n wêreldburgeroorlog. In die Oosblok sowel as in die Wesblok gaan dit steeds om die elkaar-uitsluitende alléénaanspraak op definiëring van die wese en die toekoms van die mens en van die geskiedenis.

\section{II}

Die samehang van die teenswoordige wêreldburgeroorlogsideologie en die geskiedsfilosofie van die Aufklärung kan derhalwe maklik aangetoon word. Dit het egter daartoe gelei dat geskiedsfilosofie as sodanig in die Westerse denke gediskrediteer is. Daarvan getuig nie slegs Kesting se boek nie; ook Popper se eensydige, maar nietemin treffende 
boek oor die Poverty of Historicism moet hierby gereken word. En Hermann Lübbe (1971: 11) skryf soos volg: 'Die beroep op die deurskoude gang van die geskiedenis behoort sonder uitsondering tot die belangrikste ideologiese magsmiddele. Politieke besluite wat aanspraak daarop maak dat dit lei tot die verwerkliking van dit wat in ieder geval die onvermydelike gevolg van historiese prosesse skyn te wees, verskaf daardeur legitimiteit aan sigself. Wie poog om sy politiek te begrond in 'n gepretendeerde kennis van die wêreldhistoriese doel van die mensheid, het ideologies iedere reg aan sy kant gekry.' Dan is daar natuurlik ook Marquard, wat soos reeds gesê, sulke groot 'Schwierigkeiten mit der Geschichtsphilosophie' konstateer dat hy ' $\mathrm{n}$ 'Abschied von der Geschichtsphilosophie' as onvermydelik beskou (Marquard 1973: $20 \mathrm{vv}$ ).

Daar is myns insiens drie redes waarom ons nie afskeid kan neem van die geskiedsfilosofie nie, maar waarom ons ons veel eerder vir 'n vernuwing daarvan moet beywer.

In die eerste plek is dit onmoontlik om die probleem van die geskiedenis eenvoudig te verontagsaam. Die filosofiese refleksie het nou maar eenmaal die uitdaging erken en aanvaar om die werklikheid ook as geskiedenis op te vat en uit te lê. Ons kan nie agter hierdie refleksieniveau terugval nie. Ons sal altyd bewus bly van ' $n$ tekortkoming, hoeseer ons ook al die taak om die geskiedenis as geheel te begryp afmaak as uitgedien en gevaarlik. Odo Marquard meen dat daar genoegsame vorme is waarin die filosofie kan kompenseer vir die afskeid van die geskiedsfilosofie. Maar hoe belangrik die antropologie en estetiek in die verband ook al is, dit kan die problematiek van die geskiedenis nie werklik verdring nie, laat staan nog oplos.

Die tweede rede waarom hernude geskiedsfilosofiese bemoeienis noodsaaklik is, is die volgende: Daar kan geargumenteer word dat die sosialisme as verklaringsmodel van die geskiedenis skynbaar wêreldwyd uitgedien is en gediskrediteer kan word. Dit is seker ook so dat Lenin se voorstelling dat die lande van die Derde Wêreld hulle 'noodwendig' by sy sosialistiese revolusie sou aansluit, geensins werklikheid geword het nie. En tóg kan niemand ontken nie dat die sosialistiese wêreld- en geskiedenisbeskouing oral oor steeds ' $n$ groot aanhang het en besonder werksaam is in die politiek. Dit kan na alle waarskynlikheid daaraan toegeskryf word dat universele antwoorde verskaf word, en dat mense klaarblyklik 'n behoefte het aan algemene lewensoriëntasies wat die wêreld en die geskiedenis in die geheel omvat. Kennis van alomvattende teorieë oor die wêreldgeskiedenis het ' $n$ 
stabiliserende invloed op juis die swakkere denkers, en dit is waarom hulle hulle na die sosialisme wend. Reeds in 1922 het Georg Lukács opgemerk dat die inherente swakheid van die burgerlike mentaliteit geleë is in die totale onvermoë van sy denkers en historici om die gebeurtenisse van die hede te vertolk in terme van die wêreldgeskiedenis. Bykans vyftig jaar later sê die Amerikaanse Marxis, Paul M Sweezy, dat hierdie opmerking van Lukács nog niks van sy waarheid ingeboet het nie en dat die krag van die Marxisme, in teenstelling met die burgerlike ideologie, geleë is in sy vermoë om eietydse gebeure binne 'n wêreldhistoriese samehang te interpreteer en wel op so 'n wyse dat dit nie slegs die afguns van die burgerlike mentaliteit ontlok nie, maar ook sy bereidheid tot kapitulasie (Sweezy 1970: 35-36). 'n Ideologiese geskiedsfilosofie, al is dit ook hoe simplisties en dogmaties, is kennelik vir baie nog steeds aantrekliker as (hoegenaamd) glad niks nie.

Die derde en belangrikste rede vir 'n vernuwing in die geskiedsfilosofiese besinning is die huidige wêreldtoestand en spesifiek die toestand van die wêreldpolitiek self. Ons beleef naamlik 'n eskalasie van die ideologiese wêreldburgeroorlog met al die absurde afmetings wat dit aanneem. In so 'n situasie kan dit vir die filosofie nie bloot gaan om 'n soeke na sogenaamde 'fundamenteel-Westerse waardes', wat as basis kan dien vir 'n geestelike weerbaarheidsfront nie. Die historiese situasie moet as geheel in sy ontwikkelingsgang begryp word. Die antagonisme wat daarin vervat is, moet blootgelê word, asook die moontlikhede wat dit inhou om die pynlike konfrontasie af te weer. Eers wanneer al hierdie dinge verreken is, kan daar sprake wees van 'n verantwoordelike en vasberade standpuntinname.

\section{III}

Die hernude begronding van 'n omvattende geskiedsfilosofie moet nietemin, naas die argument vir sy eie noodsaaklikheid, ook ' $n$ verklaring gee vir die mislukking van die pogings wat tot dusver aangewend is. Vir kritiek op die geskiedsfilosofie in die Verligtingstradisie, en veral op die vooruitgangsgeloof wat vanaf Perrault, Fontenelle en Holbach via Saint-Simon, Comte en Marx na die wêreldburgeroorlogsfronte van vandag deurloop, kan onder meer verwys word na die werke van Kesting, Koselleck en Marquard, asook 'n belangrike opstel oor politieke teologie wat onlangs uit die pen van Reinhart Maurer (1982) verskyn het. Hierdie kritiek sentreer rondom vier punte wat deurslaggewend was vir die ontwikkeling van die geskiedsfilosofie en die 
dilemma waarin hy hom bevind. Dit kan genoem word die filosofiese bankrotskap, die politieke bankrotskap, die teologiese bankrotskap en die historiese bankrotskap van die geskiedsfilosofie in die gees van die Aufklärung. Vervolgens wy ons 'n kort bespreking aan elk van hierdie vier punte.

\section{Die filosofiese bankrotskap}

Sedert die E17 het daar weliswaar 'n 'Wille zu sich selbst grundgebender Rationalität' (Blumenberg) posgevat. Terugskouend blyk dit egter duidelik dat dit baie makliker is om Christelik-teologiese leerinhoude te bestry as wat dit is om los te kom van die denkstrukture wat daarmee saamhang en wat deur soveel eeue heen ' $n$ vormende invloed gehad het. So het dit dan ook gebeur dat denkvorme wat op ' $n$ transendente orde betrekking gehad het, bloot op die immanente werklikheid oorgedra is: Die voleinding in ' $n$ lewe na die dood word nou vereenselwig met ' $n$ utopiese toestand iewers in die toekoms, die Skepper word 'n konglomeraat van rede en natuur, die goddelike gerig oor die wêreld word gesien as die immanente gang van die wêreldgeskiedenis of die 'finale slag' (laaste geveg) wat eenmaal sal plaasvind, en die heilsekerheid wat in die geloof gegrond is, word oorgedra op die wetenskap. Die basiese teëspraak wat daar in die samehang van wetenskap en toekomssekerheid geleë is, word verdring deur 'n aggressiewe vooruitgangsoptimisme.

Die strukturele gebrek in hierdie denkpatroon is dat dit volhard in 'n wete wat volgens hiedie denke se eie reëls streng gesproke nie gehandhaaf kan word nie. Grondliggend aan hierdie denkhouding is immers die reël dat uitsprake altyd onderworpe is aan toetsing en diskresie, en dat die geldigheid daarvan dus in beginsel betwyfelbaar/aanvegbaar is. Wil ' $n$ mens dit as beginsel van kritiese wetenskapsbeoefening in ere hou, dan kan dit onmoontlik gebruik word om die plek van die eertydse heilsekerheid in te neem. Word hierdie beginsel wél so misbruik, dan dra dit uit die staanspoor die kiem van 'n wêreldburgeroor$\log$ in homself, en moet dit gesien word as 'n anti-moderne, reaksionêre stap terug na 'n posisie vóór Hobbes en die aanvang van die Moderne tydvak.

\section{Die politieke bankrotskap}

Dit bring ons dan ook by wat genoem is die politieke bankrotskap van die geskiedsfilosofie in die gees van die Aufklärung. Dit hang saam met 
die revolusionêr-subversiewe uitgangspunt wat die Aufklärung-tradisie van die begin af domineer. Die tipiese Aufklärer is ' $n$ individualis. $\mathrm{Hy}$ is aangewese op sy eie deugde en begaafdhede. Hy soek wel na 'geesgenote' met wie hy in 'n klub of vereniging saam kan verkeer, maar die ekstreme individualis voel homself verplig om in opposisie te verkeer met die beskikbare politieke instellings. Die géwigtige status daarvan moet in die naam van vryheid en geregtigheid teengewerk word. Daarby betrek hy homself graag op 'die mensheid'. As revolusionêr moet die Aufklärer afsien van die konkrete politieke bemiddelingsproses, want dít is na alles wat hy eintlik verafsku. In so 'n abstrakte sfeer tussen individu aan die een kant en mensheid aan die ander kant, gebeur dit onvermydelik dat iedere motivering vir die lewe vermoraliseer word. Die deugsaamheid wat nagestreef word, word uiteindelik onverbiddeliker as enige despoot, en word mens eenmaal gewoond aan hierdie gestrengheid van die revolusionêre etiek, gebeur dit maklik dat iemand wat hom nie daarmee vereenselwig nie, gebrandmerk word nié slegs as 'vyand' nie, maar as 'vyand van die mensdom'. Trouens, die gestrengheid van die deug kan daarop uitloop dat 'n nuwe despoot weer aanvaar en met absolute gesag beklee word.

Die rigorisme wat gepaard gaan met die oordrag van ' $n$ transendente heilswaarheid op die mundane werklikheid en die mensheid, moet noodwendig burgeroorlogsfronte laat ontstaan. In hierdie omstandighede sou dit wys wees om die staatsfilosofie van Hobbes (kyk o a Willms 1970; Schmitt 1982; Bermbach \& Kodalle 1982) weer in herinnering te roep. Belangrik is veral die feit dat hy sy siening van die staat as 'Leviathan' ontwikkel het teen die agtergrond van die konfessionele burgeroorloë in die E17. Soos wat dit met alle waarlik groot filosofieë die geval is, was ook Hobbes se Leviathan 'n antwoord op die konkrete uitdagings van sy tyd, wat hy dan raakgesien het in die konfessionele burgeroorlog wat daar gewoed het. Vir Hobbes is die Leviathan 'die met groot inspanning verhinderde burgeroorlog'. Anders as in die Bybel word die Leviathan in ' $n$ positiewe lig gestel. Dit is geen monster nie, maar 'n groot 'masjien', 'n 'reusagtige mens', 'n 'sterflike god'. Hierin kom tot uitdrukking dat die staat deur mense gekonsipieer en opgerig moet word, dat dit sy uitgangspunt in individue het en voortdurend aan hulle teruggekoppel moet kan word, dat dit eintlik self 'n individu is en dat dit, soos die Skepper, die grond is vir die konkrete bestaan van mense. Dit is met ander woorde ' $n$ god aan wie se voortbestaan en onderhoud, juis omdat dit sterflik is, onophoudelik gearbei moet word. En met Calvyn is Hobbes dit eens dat die 'Leviathan' in 
stand gehou moet word om die mens te verlos van 'n angs vir die dood, en so die grondslag te verskaf waarop die menslike bestaan, maar meer nog: alle reg, gemeensaamheid en kultuurontplooiing in rustigheid kan gedy (Hoepfl 1982).

Die staatsopvatting van Hobbes antisipeer die hele gees van moderniteit wat staan in die teken van grootskaalse neutraliseringe (Schmitt 1963: $79 \mathrm{vv}$ ), nié slegs in die politiek nie, maar ook op die gebied van die wetenskapsbeoefening. Die neutraliserings (en ons kan dit ewe goed ook sekulariserings noem) het 'n heilsame uitwerking gehad wat vandag helaas nie naastenby genoeg op prys gestel word nie. Daardeur is die mens immers onthef van die ondraaglike las om in hierdie wêreld op te tree as verteenwoordiger van die Goddelike intellek. Insgelyks is die mens gevrywaar van die vrees dat hy deur sy politiek of wetenskapsbeoefening of watter ander kultuuruiting ook al, dalk God se oordeel op die een of ander wyse kan kompromitteer. Deur onder meer die instellings van 'n konfessieneutrale staat en wetenskap is die mens prinsipieel vrygespreek van die moontlikheid tot kettery.

Soos reeds gesuggereer, het die gevaar van burgeroorlog in ons eeu weer sterk na vore getree, en dit hang ongetwyfeld saam met die neiging tot ' $n$ rekonfessionalisering van die waarheid (Marquard 1981:47 praat van 'n 'Übertribunalisierung' van die werklikheid) waaraan veral die geskiedsfilosofie medepligtig was. Polities gesproke beteken dit beslis ' $n$ regressie op die posisie van Hobbes. Die toppunt hiervan is te vind in die herinterpretasie wat gegee is van die vriend-vyand-verhouding wat aan die wortel lê van alle politieke aktiwiteit. Politiek is van oudsher die kuns van die onderskeiding tussen vriend en vyand (Carl Schmitt). In die era van die geskiedsfilosofie word die min of meer neutrale begrip 'vyand' egter gelykgestel met die begrip 'misdadiger'. Hiermee word daar 'n morele kleed oor die politiek getrek, en word die outonome status van die politiek misken. Die vermoralisering van die politiek het bedenklike gevolge. Dit haal alle elemente van ridderlikheid en 'fair play' uit die politiek. Waar die vyand uitsluitlik in moralistiese terme geoordeel (veroordeel!) word, lei dit tot ' $n$ verhewiging in die intensiteitsgraad van die vriend-vyand-onderskeid. Hierop het veral Carl Schmitt (1979) gewys. In sy voordrag Die Tyrannei der Werte skryf hy soos volg: 'Vir die hoogste waarde is die hoogste prys nie te hoog nie.... Enige konsiderasie vir die vyand hou op om te bestaan, of word selfs ' $n$ onwaarde, sodra die stryd teen die vyand gevoer word in die vorm van hoogste waardes. Die onwaarde het dan geen reg meer teenoor die waarde nie, terwyl geen prys meer te hoog is vir die verwe- 
senliking van die hoogste waardes nie. Die gevolg hiervan is uitdelgers en uitgedelgdes.'

\section{Die teologiese bankrotskap}

Die teologiese bankrotskap is daarin geleë dat die Aufklärung sélf hom aan ' $n$ betreklik minderwaardige, kleingeestige teologie gaan oriënteer het in sy pogings om die (transendente) heilswaarhede van die Christelike geloof te vertaal in terme van die hier en die nou. Reinhart Maurer (1982) is van mening dat die universalisme wat gepaard gaan met die Aufklärung en wat by Marx 'n hoogtepunt bereik, histories 'n struktuurooreenkoms met die voor-Augustiniese Chiliasme toon. Die Chiliasme verteenwoordig ' $n$ vervalsvorm in die geskiedenis van die Christelike teologie, en is as sodanig uit die staanspoor deur groot teoloë soos Origenes en Augustinus bestry - veral vanweë die latente fanatisme daarin. Gesien vanuit die standpunt van Augustinus (wat 'n voortsetting vind by Luther, Hobbes en Hegel), kom die Chiliasme neer op ' $n$ ongeoorloofde vermenging van godsdiens en politiek, civitas dei en civitas terrena, kerk en staat. Juis in die Christendom kan dit gevaarlike konsekwensies hê. In die meeste ou godsdienste is die verbinding van godsdiens en politiek onproblematies. By die Christendom word dit egter hoogs problematies omdat hier uitgegaan word van die voorstelling en begrip van ' $n$ bowe-wêreldlike en daarmee ook 'n bowe-politieke God. Hier kan dan 'n teenstrydigheid ontstaan, naamlik dat 'n opperwese wat veronderstel is om bo die politiek verhewe te wees, hom tóg (via die gesindhede van diegene wat aan hom glo) in die politiek inmeng.

Die Christendom bring 'n element van dubbelsinnigheid in die spel. Enersyds word daar gestel: 'My koninkryk is nie van hierdie wêreld nie' (Joh 18:36), maar andersyds: 'Die koninkryk van die hemele is soos suurdeeg wat 'n vrou neem en in drie mate meel inwerk totdat dit heeltemal gerys is' (Matt 13:33). Die genialiteit van Augustinus (naas ander groot teoloë) lê daarin dat hy 'n gevoeligheid openbaar het vir hierdie dubbelsinnigheid en die onopgeloste spanning wat daarin opgesluit lê. Daarenteen gaan die Chiliaste uit van 'n oorvereenvoudigde sin-kontinuïteit tussen God, skepping en mensheid. So 'n teologie het ooglopende voordele as die primêre oorweging dié is van 'geestelike versorging', stigting en vertroosting van die massas. Bybels gesproke is dit natuurlik dié soort teologie wat ons by Job se vriende aantref: 'n Teologie wat die sin van die lewe en die handelinge van God op 'n 
vroom manier wou verklaar aan die hand van maatstawwe wat by die deursnee menslike denkwyse aangepas is.

Die geskiedsfilosowe van die Aufklärung het met hulle idee van 'n alomvattende rasionaliteit net op 'n ander manier hierdie simplistiese voorstelling van 'n sin-kontinuiteit voortgesit. En soos die teoloë van ouds het ook die geskiedsfilosowe nou voor die probleem van die kwaad te staan gekom. As daar uitgegaan word van 'n sin-kontinuum in die geskiedenis, hoe rym dit dan met die verskynsel van die kwaad wat hom in soveel gestaltes aan ons opdring? Inderdaad 'n moeilike probleem, maar die draers van die Verligting het 'n eenvoudige oplossing hiervoor gehad: Hulle laat die eintlike geskiedenis eers met hulle eie Aufklärung 'n aanvang neem. Alles wat dit voorafgaan, hoort tot die 'slegte voorgeskiedenis van die mensdom' (Marx). Daarmee word die kwaad in beginsel skadeloos gestel. Die vooruitgang wat die waarlik verligte mensdom maak, sal 'n einde bring aan alle euwels. ' $n$ Latere weerklank van hierdie mentaliteit vind ' $n$ mens onder andere in die feit dat in die Sowjetunie vandag nog doodgewone natuurrampe sover moontlik verswyg word deur die media - om nie eens te praat van ander rampe en ellendes nie. Ook by ons is 'n aansienlike deel van die offisiële politiek daarop afgestem om die mense te paai, hulle gemoedere te kalmeer, en hulle te verseker 'dat sake volkome in beheer is'.

Benewens 'n aardse paradys vir die bekeerdes, skep die profane heils-ideologieë ook 'n aardse hel vir die 'vyande van die mensdom' waarby hulle met laasgenoemde beslis meer sukses het as met eersgenoemde. Marquard (1981: 132-133) wys in dié verband op 'n merkwaardige ontwikkeling wat nogmaals die teologiese bankrotskap van

Die geskiedsfilosowe van die Aufklärung het met hulle idee van 'n teologie 'n duidelike neiging is weg van dogmatiese uitsprake, daar kry ons in die geskiedsfilosofie net mooi die teenoorgestelde ontwikkeling. Die teologiese fakulteite het ná die Reformasie (en heeltemal in pas met die gees van moderniteit) al hoe meer die karakter van 'n filologieshistoriese fakulteit begin aanneem. Dit het gelei tot ongekende prestasies op akademiese gebied, en dit geld nie net vir die Protestantse teologie nie, maar ook vir die Katolieke. Beide (en ek beklemtoon: beide) het immers die Reformasie deurgemaak en op sy eie manier die gevolge daarvan vir homself verwerk. 'n Teologie wat vandag nog voor-Reformatories is, moet 'n mens wel elders gaan soek. En jy kry dit, naamlik in die moderne geskiedsfilosofie wat eintlik anti-modern is, en eintlik ook geen gesekulariseerde teologie (Löwith) nie, maar (soos wat Marquard dit stel) 'die enigste teologie waarby die sekularisering tot 
dusver misluk het' - 'n teologie kompleet met Heilige Skrif, kerklike leeramp, ortodoksie, kettery, Kategismus, banvloek, en waar moontlik ook 'n duiwel, of hy nou Kapitalisme heet of wat ook al anders.

Die anti-moderne inslag van die geskiedsfilosofie kom in die laaste instansie dáárin tot uitdrukking dat dit opnuut stukrag gee aan die motief van 'n eskatologiese wêreldnegasie (voleindiging as vernietiging van die wêreld). Daarmee speel dit aan by elemente wat in die vóór-moderne Christendom, en meermale in die Chiliastiese tradisie, skerp geaksentueer en selfs op die spits gedryf is: Dit is naamlik die kwessie van die Joodse apokaliptiek asook die sogenaamde Johannesapokaliptiek. In respektabele teologiese kringe is en was daar nog altyd 'n neiging om die gedagte van 'n apokaliptiese wêreldeinde af te skaal. 'n Mens kry selfs die indruk dat dit 'n verleentheid geword het. Vandaar allerlei pogings om dit deur gedifferensieerde interpretasie-strategieë 'af te bou' of te 'dekonstrueer' en dit skyn heeltemaal in pas te wees met die gees van moderniteit. Die onderliggende motief van die moderne periode is immers dié van 'n afkeer aan die eskatologiese wêreldnegasie (Marquard 1981a). Dit is, soos wat Hans Blumenberg (1966: 75-200) heeltemaal tereg opgemerk het, 'n wêreld-konserwatiewe motief. Die moderne era is die eintlike konserwatiewe era, en daarin het hy sy legitimiteit. Die moderne era moet verstaan word as ' $n$ wêreld-konserwatiewe repliek op die motief van 'n eskatologiese wêreldnegasie. Vandaar die noodsaaklikheid om die waardigheid en eer van hierdie wêreld te herstel, onder andere deur 'n einde te maak aan die digotomie van 'Sein' en 'Sollen', asook aan die skeppingsmetafisiese vraag 'waarom is daar iets en nie veel eerder niks nie?'. Die vraag na ' $n$ absolute aanvang en ' $n$ absolute voleinding kom voort uit 'n basiese onvergenoegdheid met die bestaande werklikheid - 'n misnoeë in die lewe. Die bestaande werklikheid is by voorbaat reeds in die ongelyk gestel. Dit word gediskrediteer ten gunste van die sogenaamde 'ware werklikheid' waarin dit sy oorsprong en voleinding sou hê. Daar is ' $n$ volkome disjunksie tussen waarheid en werklikheid, en dit bring mee dat die bestaande werklikheid aan ' $n$ permanente legitimasiedwang onderwerp word. Die bestaande orde word genadeloos in die beskuldigdebank geplaas. Hy word gedwing om homself te legitimeer of te regverdig. Die totale bewyslas rus op hom om aan te toon dat daar inderdaad regverdiging is vir sy voortbestaan.

Teen hierdie absolute eis om legitimasie kom die moderne lewenshouding in opstand. Die bewyslas word omgekeer. Dit berus nie by die 
bestaande werklikheid nie, maar by diegene wat dit radikaal wil verander om die nodige regverdigingsgronde aan te voer. Intussen geld minstens die primêre vermoede dat die bestaande werklikheid redelik oftewel legitiem is (kyk Lübbe 1977: 329-330; 1978: 130-132; Marquard 1979: $331-342$ ).

Die moderne lewenshouding kan met die beste wil ter wêreld nie insien waarom die mens permanent gebukkend moes gaan onder die las van 'n absolute eis om legitimasie nie. Die lewenslustigheid van die moderne mens kan nie versoen word met ' $n$ basiese houding van onvergenoegdheid en misnoegdheid met die lewe nie. Die moderne mens soek ook na waarheid, maar vir hom impliseer die waarheidsoeke geen askese nie. Die moderne mens het geleer dat dit een ding is om die waarheid na te streef, maar 'n ander om met die waarheid saam te leef. Dit gaan vir hom ten diepste om ' $n$ leefbaarheidsrelasie met die waarheid - 'n relasie waarin dit vir die mens draaglik gemaak word om met die waarheid saam te leef en dit met hom uit te hou. En só 'n situasie waarin daar optimaal ruimte gelaat word vir spontaneiteit, kreatiwiteit en spel, is totaal ondenkbaar waar die pluriformiteit van die waarheid misken word - waar daar aangedring word op 'n uniforme, absolute waarheid. Die moderne waarheidsopvatting kom neer op 'n pluralisering in teenstelling tot ' $n$ singularisering van die waarheid. Dit is waarom die skeppingsmetafisiese vraag na ' $n$ absolute oorsprong van alles al hoe meer op die agtergrond geskuif word. Dit is waarom die eis om 'n eksplisiete begronding van die totale werklikheid verwerp word. Bevry van die ondraaglike las om alles te moet begrond en ewig verantwoording te moet doen van die werklikheid in sy geheel (die mens is immers nie God wat die werklikheid só geskep het nie!) kan die mens hom wy aan die hier en die nou. Dit beteken geen kritieklose boedeloorgawe aan die bestaande orde nie. Om modernisme met kritiekloosheid te identifiseer, is absurd. Maar wat dit wel beteken, is die erkenning dat die mens mens is en nie God nie: dat die mens eindig is. Hy is sterflik. Die lewe is kort (vita brevis), en ons het eenvoudig nie die tyd èn die vermoë om alles te bevraagteken en krities te ondersoek nie. Ons moet rekening hou met die 'Unvermeidlichkeit von Üblichkeiten' (Marquard 1979) in ons lewe - daardie oorwig van vanselfsprekendhede wat aan ons leefwêreld 'n objektiewe diepgang, kontinuiteit en duursame kwaliteit verleen. Geen mens kan hom na willekeur distansieer van wat hy is nie. Daar is en bly iets soos die ondistansieerbare; dit wat die mens eenvoudig vitaal repeteer; dit wat die mens nie aan kritiese interpretasie en begronding kan onder- 
werp nie, maar wat hy bloot nog is. Die mens se bestaan is in die laaste instansie onoplosbare en onontrafelbare gegewenheid (faktisiteit).

'n Denke wat erns maak met die eindigheid en faktisiteit van die menslike bestaan is ' $n$ denke wat staan in die teken van ' $n$ 'Abschied vom Prinzipiellen' (Marquard 1981). So 'n denke staan noodwendig skepties teenoor enige poging om die wêreld en die geskiedenis te verklaar vanuit ' $n$ enkele oerprinsipe. So 'n denke is noodwendig ook anti-Christelik as dit in die Christendom bloot net sou gaan om die verkondiging van 'n eenvoudige sin-kontinuiteit tussen God en sy skepping. Maar gelukkig omvat die Christelike tradisie veel meer as dit. Die Christelike tradisie beskik oor ' $n$ ontsaglike innoveringspotensiaal wat aan hom 'n duursaamheid gee wat seker ongeëwenaard is. Telkens wanneer die Christendom dreig om te verstar in 'n vrome wêreldverklaringsisteem, het daar die groot vernuwers in die teologie na vore getree.

Daar is reeds verwys na Augustinus en sy stryd teen die fanatisme van die Chiliaste. Belangrik is ook die sogenaamde 'via moderna' wat as teologiese stroming sedert die E11 begin opgang maak het. Tradisioneel staan dit bekend as Nominalisme, wat veral in die werk van Willem van Ockham voortreflik tot uitdrukking gekom het. Ons kan nie hier op die filosofiese en teologiese inhoud van Ockham se denke ingaan nie; belangrik is in ieder geval sy verset teen leerstelsels wat God as rasionele verklaringsprinsipe wou gebruik, en sy aandrang daarop dat God as die waarlik transendente, die 'Gans Andere' gerespekteer moet word. Hiervolgens is hierdie wêreld in ieder geval kontingent. Met ander woorde, God sou, as mens met sy Almag wil erns maak, die wêreld ook heel anders kon geskep het. Daar is dus geen harmoniserende sin-kontinuïteit tussen die immanente en die transendente werklikheid nie. Daar is dan ook geen kans vir die menslike denke om die goddelike sin in die geskape heelal op te spoor nie. Die mens moet dit self in die hier en die nou telkens verwerklik. Die kontingensie maak die wêreld geensins sinloos nie. Inteendeel; dit skep juis die geleentheid vir werklike rasionaliteit in 'n 'relativen Autonomie des Zeitlichen' (Maurer 1982: 359) wat reeds deur Augustinus erken is, veral in die betekenis $w$ at dit het in die skepping van ' $n$ vreedsame toestand in die hier en die nou.

Van wesenlike belang is vir ons ook die politieke konsekwensies van Ockham se denke. Hieraan is daar heeltemal nog te min aandag in filosofiese literatuur gewy. Verdienstelike werk is nietemin deur Bernard Willms (1983) gelewer. Willms wys onder meer daarop dat daar in 
die teologie van Ockham 'n selfstandige en betekenisvolle stelwaarde aan die politiek toegeken word. Na sy mening is dit ook nie toevallig dat Thomas Hobbes in die tradisie van die Nominalisme staan nie.

Samevattend kan ons stel dat die teologiese bankrotskap van die geskiedsfilosofie daarin geleë is dat hy verbind gebly het aan die verkapte en uitgediende konsepte van wat breedweg genoem kan word die 'Chiliastiese onderstroming' in die Christelike tradisie. Daardeur het die geskiedsfilosofie nie alleen tred verloor met die innovasies wat daar in die Christendom plaasgevind het nie, maar het dit tegelyk ook vasgesteek in 'n vóór-moderne (inderdaad anti-moderne!) lewenshouding sonder om ag te slaan op die gevare wat dit inhou - gevare waaraan ons myns insiens slegs kan ontkom deur 'n konsekwente en volgehoue toeëiening van die gees van moderniteit soos wat ek dit hierbo kortliks getipeer het. Belangrikste van alles bly steeds dat ons sal waak teen ' $n$ rekonfessionalisering en ' $n$ singularisering van die waarheid. Wat die verhouding godsdiens en politiek betref, impliseer dit ' $n$ soort negatiewe politieke teologie wat voortdurend waak teen 'n té kompakte verhouding tussen godsdiens en politiek en die fanatisme wat daaruit voortvloei.

Uitmuntende voorbeelde van so 'n negatiewe politieke teologie het ons nie slegs in Augustinus, Ockham, Luther en Hobbes na wie reeds verwys is nie; daar is (soos altyd waar daar sprake is van grootsheid en voortreflikheid) natuurlik ook Hegel. So kan ek verwys na die gedeelte in Hegel se Grundlinien der Philosophie des Rechts (para 270, Zusatz) wat handel oor die verhouding Staat en godsdiens. Daarin skryf Hegel onder meer die volgende: 'Wanneer die godsdiens homself in die staat wil laat geld soos wat hy op sy eie terrein gewoond is, dan sal dit die staat se organisasie omverwerp, want in die staat staan die onderskeie lewensfere naas mekaar, elk in sy eie reg: In die godsdiens daarenteen is alles altyd op die totaliteit betrokke.... Dit is fanatisme om die onderskeidinge in die lewe nie te respekteer nie.' Heelwat vroeër reeds het Hegel die oortuiging uitgespreek dat dit fanatisme is 'das Ewige, das himmelreich als solches auf Erden einführen zu wollen, $\mathrm{d} h$ der Wirklichkeit des Staates entgegen' (kyk Maurer 1982: 354 voetnoot 10).

Vir diegene wat nog soos die Chiliaste droom van 'n toekoms waarin die mense, gerugsteun deur broederlikheid en liefde, saamwoon in vryheid en gelykheid - vir al diesulkes hou Hegel 'n waarskuwing in. By Hegel hang die godsdienskritiese begrip 'fanatisme' ten nouste saam met die politiekkritiese begrip 'totalitarisme'. Die skakel tussen die twee vind Hegel in ' $n$ pervertering van die Christelike liefde in die 
oorspronlike sin - daar waar hierdie liefde homself te buite gaan en te ver gevoer word. Volgens Hegel was die liefdesgebod oorspronklik van toepassing daar waar persone ten nouste met mekaar saamgeleef het in konkrete daaglikse situasies. Die liefde kon 'n kragtige saambindende faktor in die oer-Christelike gemeentetjies wees. In die groter politieke opset werk hierdie liefde egter destruktief wanneer dit hom sonder voorbehoud wil laat geld. Die liefdesaanbod kan oorgaan in 'n dreigement: 'Und willst du nicht mein Bruder sein, so schlag ich dir den Schädel ein.' Hieroor skryf Hegel soos volg: 'Die onnatuurlike uitbreiding van die omvang van die "liefde" kan homself vaswikkel in 'n teëspraak, in 'n valse strewe, wat die vader moet word van die verskriklikste fanatisme' (kyk Maurer 1982: 354).

Reinhart Maurer (1982: 354) is van mening dat 'n persoon soos Habermas (om maar een te noem) nie genoegsaam kennis geneem het van hierdie waarskuwende woord van Hegel nie - veral daar waar hy in Theorie und Praxis (bladsy 200) 'n byna Chiliastiese toekomsblik bied op 'n 'vergöttlichte Menschengattung' wat hom 'uiteindelik in liefde aan die mensgeworde God laat verbind'. Hierteenoor, en in aansluiting by Hegel en Nietzsche, kritiseer Arnold Gehlen die etos van die mensliewendheid ('Humanitärethos') en sy alléénaanspraak op geldigheid in die politiek as 'n geforseerde ekstrapolasie van die oorspronklike familie-etos (Moral und Hypermoral 1969).

Hiermee is genoeg gesê oor die teologiese bankrotskap van die geskiedsfilosofie. Ek sou vanselfsprekend graag ' $n$ draai wou maak by Nietzsche, maar ek wil uitkom by wat vroeër genoem is die historiese bankrotskap van die Aufklärung en sy filosofie van die geskiedenis.

4. Historiese bankrotskap van die Aufklärung en sy filosofie van die geskiedenis

Hier kortliks net die volgende: Die geskiedsfilosowe van die Aufklärung het weliswaar uitgegaan van die wêreld, menende die aarde in sy geheel. En tog was hulle beskouings gebou op die smalle basis van die Europese rasionalisme en die Europese beskawing. Enersyds was daar diegene wat die sogenaamde 'primitiewe' of 'barbaarse' mense so gou doenlik wou ophef tot die standaarde van die Europese beskawing. Andersyds was daar diegene wat die sogenaamde bon sauvage (noble savage) tot 'n toonbeeld van voortreflikheid verhef het. Watter van hierdie standpunte ook al gehuldig is - die voorstelling van 'n ideale mensheid waarheen die geskiedenis moes beweeg, was uit die staan- 
spoor begripsimperialisties (vgl die insiggewende werk van Bitterli 1976:207 vv en $367 \mathrm{vv}$ ). Vroeër of later moes dit dan ook aanleiding gee tot ' $n$ ideologie van imperialisme: die argelose imperialisme van weleer, en die arglistige Sowjetimperialisme van vandag.

\section{IV}

Om hierdie tekortkominge in die geskiedsfilosofie van die Aufklärung uit te wys, beteken nog nie dat dit te bowe gekom is nie. Wie 'n voorstander van 'n vernuwing van die algemene geskiedsfilosofie is, is in sy strategie gelukkig nie slegs op homself aangewese om bestaande gebreke te oorkom nie. Die filosofiese dilemma kan deur filosofiese refleksie te bowe gekom word. Hier sal 'n mens met groot vrug kan aanleun by die grootse filosofieë van onder meer Hobbes en Hegel, en veral by die politieke en geskiedsfilosofiese konsekwensies van hulle denke. Veral Hegel is heeltemal ten onregte gereken tot die Chiliastiese linie wat strek deur die Aufklärung en sy geskiedsfilosofie heen tot by die ideologiese wêreldburgeroorlog van vandag. Immers, vir Hegel was slegs dit redelik ('vernünftig'), dit wil sê filosofies konstrueerbaar, wat ook werklik is ('wirklich'), dit wil sê in die geskiedenis reeds daadwerklik sy opwagting gemaak het. Heeltemal ten onregte doen die Marxisme-Leninisme hier 'n beroep op Hegel.

In aansluiting by die 'grootse filosofië̈' kan die filosofiese gebreke oorkom word, net soos wat mens die teologiese bankrotskap te bowe kan kom deur te breek met die harmoniserende middelstandkonformisme van die Aufklärung èn die teologie waarvan dit ' $n$ afskynsel was.

Die politieke bankrotskap soos ook die historiese, kan opgehef word deur 'n behoorlike rekenskap van die objektiewe voorwaarde van ons huidige wêreldervaring, en veral die ervaring dat mensheidsvoorstellinge as sodanig net tot absurde antagonismes gelei het.

Ek wil my graag aansluit by die skerpsinnige Duitse politieke filosoof Bernard Willms (1977; 1982: $32 \mathrm{vv})$ wanneer hy soos volg beweer: 'Die enigste wat ons as die werklike resultaat van alle geskiedenis tot hier toe kan erken, is die vorming van nasionale state dwarsoor die ganse aardbol. Dit is die uitkoms van die E20: Nié 'n "klaslose" maatskappy nie; nié "one world" nie, maar 'n geslote pluraliteit van nasies.'

Willms meen dat dit van kardinale belang is om hierdie ervaring van die werklikheid deeglik van dié van die Europese Aufklärung af te grens. Die wêreldwye dekolonialisasie wat die E20 in so 'n groot mate bepaal het, is van groot betekenis. Waar dit vroeër gegaan het om 
politieke subjekte of wêreldmagte wat in kolonialisme teenoor politieke objekte te staan gekom het, daar gaan dit vandag om 'n geslote pluraliteit van politieke subjekte. Die politieke selfbewussyn, die strewe na ' $n$ afsonderlike politieke identiteit en selfbeskikking is tans wêreldwyd verbrei. Dit is ' $n$ universele werklikheid. Die nog bestaande imperialismes soos dié van die Sowjetunie kan derhalwe as reaksionêr bestempel word.

Die radikale Aufklärer en anargistiese sosialis, Proudhon, het eenmaal gesê: 'Wie God sê, wil bedrieg.' Carl Schmitt (1963:xx) het hierdie formulering verander na: 'Wie Mensheid sê, wil bedrieg.' Sedert die dae van Aristoteles weet ons reeds dat die mens 'n 'zoon politikon' is, dit wil sê dat hy konkreet slegs in 'n bepaalde politieke gemeenskap bestaan, en dat hy slegs só (aldus polities) 'n identiteit kan hê. Toe die Griekse stadstate begin verval en daar geleidelik groter en groter politieke groeperinge ontwikkel wat die ou grense laat vervaag het, het mense hulleself uiteindelik veral in die tyd van die Aufklärung begin sien in terme van 'die mensheid'. In die globale kommunikasie-gemeenskap van vandag is die begrip 'mensheid' geen spekulatiewe begrip meer nie: Dit is eenduidig en sonder meer insigtelik. En tóg is dit so dat die mens - hoeseer hy ook al op die mensheid in die algemeen betrokke is - konkreet altyd nog leef binne die raamwerk van 'n spesifieke politieke orde of nasie, al lê daar ook hoeveel onordelikheid en gebrek aan identiteitsbesef daarin opgesluit. Hierdie ontwikkeling van 'n politieke, nasionaal-staatlike bestaan vir alle mense - die bestaan in die besef dat jy deel is van 'n nasie - dít is die weg en daarmee ook die sin van alle geskiedenis tot hiertoe. En dit is nie iets wat as voorskrif vir die toekoms uitgedink is nie, maar ' $n$ feit wat hom in die konkrete ervaring aan ons opdring. Die begrip 'nasie' bevat in homself die waardigheid en verhewenheid van 'n noodwendigheid wat aan ons geen ander opsie laat nie.

In die idee van die nasie vind ons ' $n$ bemiddelingsterm wat ' $n$ versoening tussen individu en mensheid bewerk. Soos wat die individu sy identiteit en sy waardigheid slegs binne die politieke raamwerk van die nasie waarvan hy deel is, besit, só is ook die mensheid vandag slegs te bedink in terme van ' $n$ veelheid van nasies wat $d$ warsoor die wêreld in politieke selfbewussyn bestaan.

Wanneer die idee 'nasie' in die middelpunt gestel en gesien word as die bemiddelingsfaktor tussen mens en mensheid, kan die geskiedsfilosofie ontkom aan die gevaarlike perspektief van 'n wêreldburgeroorlog en die gewrakkte veralgemenings wat op 'n moralistiese en buro- 
kratiese wyse op ons afgedwing word. Ek sê dat ons hierdie dinge kan vermy, want die idee van die nasie as die sin van die geskiedenis beteken bo alles veelvoud. Daar is gewoon niks denkbaars in die konkrete hier en nou wat ons bo die idee van die nasie kan verhef nie. Waar ook al die een of ander idee bó die van die nasie gestel word, het 'n mens met niks anders te make as die ideologiese vergoeiliking van 'n spesifieke nasionale magsaanspraak nie. Die beste voorbeeld hiervan het on in die identifisering van die sosialistiese 'mensheidsidee' met die belange van die Sowjetunie. (Vergelyk Stalin se opvatting van Rusland as die 'moederland' van die internasionale Kommunisme - die moeder wat te alle tye en sonder enige voorbehoud vooropgestel moet word.) Hier tree die perspektief van 'n wêreldburgeroorlog in sy volle skerpte na vore.

Die absurditeit van die hele ontwikkeling vanaf die geskiedsfilosofie van die Aufklärung tot en met die wêreldburgeroorlogsfronte van ons eeu, is dat daar oorspronklik gepoog is om deur die progressiewe perspektief van 'n toekomstige wêreldvrede weg te kom van die euwel van oorlog en geweld waardeur die mense geteister is. In die proses het dit egter oorloë ontketen wat die vroeëre oorloë na kinderspeletjies laat lyk.

Nou kan daar natuurlik met reg gevra word of die idee van die nasie nie maar net so gelaai is met die moontlikhede van geweld en oorlog nie. Hierdie vraag is deel van die vraagstuk wat vroeër die 'teodisee' genoem is: Die vraag na 'n verklaring van die bose, en 'n vraag wat ons in ons vernuwing van die geskiedsfilosofie beslis nie kan ontwyk nie. Odo Marquard (1973:59) beskryf die idealistiese oplossing wat veral Kant en Fichte vir hierdie vraagstuk gehad het, soos volg: '. . nie God is vir hierdie slegte wêreld verantwoordelik nie, want dit is nie Hy wat dit maak en onderhou nie, maar iemand anders, naamlik die mens.... Die nadruk wat hierop geplaas is, meer as enigiets anders, maak die wese van die Idealisme uit. Die Idealisme is ' $n$ teodisee met behulp van die outonomie-tese: Die tese naamlik dat God nie die skuldige is nie; nie Hy maak en onderhou die wêreld nie, maar wel die mens.'

Binne die raamwerk van die Aufklärung en sy vermoralisering van die problematiek van die kwaad, het hierdie standpunt van die menslike outonomie egter gelei tot die skepping van wêreldburgeroorlogsfronte: die absolute en genadelose skuldtoewysing van een groep mense aan 'n ander; die terroriserende aanwys van sondebokke of sogenaamde 'vyande van die mensdom'.

Die vraag is nou: Hoe staan dit met die probleem van die kwaad (van 
oorlog en van geweld) in 'n geskiedsfilosofie wat die idee van die nasie vooropstel? Hier lyk dit vir my sal 'n mens moet toelaat vir die kwaad. Dit skyn dan ook heeltemal in lyn te wees met die gees van moderniteit wat (as ek Marquard 1981a reg verstaan) juis deur middel van ' $n$ 'permission du mal' - 'n positivering van die kwaad - die hele teodiseekwessie voer tot ' $n$ radikale uiterste. Die positivering van die kwaad ('Entüblung der Übel' - Marquard) was uiteindelik die enigste manier waarop die wêreldkonserwatiewe moderne mens effektief weerstand kon bied teen die idee van 'n eskatologiese wêreldnegasie.

Kyk ons nou na die ontstaan en opkoms van die nasionale state, elk met sy eie politieke selfbewussyn, dan moet ons in alle nugterheid konstateer dat dit nie sonder geweld en oorloë plaasgevind het nie. En dit is die geval omdat hier nie teruggeval kan word op ' $n$ aprioriese beginsel, 'n natuurlike reg of natuurlike grense nie. Die mensheid kon sigself tot 'n universum van nasies ontwikkel slegs deur geweld en teengeweld. Wat' $n$ mens in hierdie ontwikkelingsgang ervaar, is nietemin méér as net sinlose bloedvergieting. Hier is immers ook sprake van ' $n$ 'stryd om die reg tot selfbeskikking'. En volgens Willms berus die reg op selfbeskikking op 'n 'Anerkennungssystem': 'n Sisteem waarin regte wedersyds gerespekteer word. So 'n sisteem kan nie apriories gekonstrueer word nie. Dit sal ook nie uit die lug val nie. Dit is volledig kontingent en kan slegs deur volgehoue inspanning in stand gehou word. ' $n$ Vreedsame en geweldlose afweging van belange is wel moontlik, maar as gevolg van ' $n$ bevolkingstoename en die begrensdheid van lewensruimte is dit onwaarskynlik.

Die ontwikkeling van 'n netwerk van nasionale state wat vandag die hele aardbol omspan, en die idee 'nasie' wat daardeur na vore gestoot is, is gelaai met geweld, maar daar is geen geskiedsfilosofiese alternatief daarvoor nie - in elk geval nie die vermoralisering van die geskiedenis soos wat dit in die Aufklärung plaasgevind het nie. Laasgenoemde het immers, veel meer as enigiets anders, gelei tot die wêreldburgeroorlogsfronte waarin ons vandag vasgevang sit. Die idee 'nasie' omvat in homself die oerbeginsel van die politiek, naamlik die onderskeiding tussen vriend en vyand (Carl Schmitt) - 'n onderskeiding wat die onvermydelike voorwaarde is vir alle ontwikkeling. Kultuurontplooiing gebeur nie sommer so vanself nie: Dit geskied op die basis van die konkrete politiek, en hierdie feit kan nie deur abstrakte begrippe soos 'mensheid', 'publikum' of 'samelewing' verdoesel word nie. Die mens se bestaan is in die politiek gewortel, en in die moderne tydsgewrig is dit die politiek van die nasionale state. 
Die steriliteit en angs van die huidige burgeroorlogsituasie kan slegs beredder word wanneer die idee 'nasie' die nodige erkenning kry. Ons sal niks regkry met oproepe tot vrede en versoening, of met fantasieë van 'n 'wêreldstaat' nie. Ook nie met nuwe politieke teologieë nie.

Die politieke bestemming van die E20 is geleë in 'n erkenning van die verskeidenheid van nasionale state en hulle reg op politieke selfbeskikking. En volgens Bernard Willms hoef ons nie te ver te gaan soek na riglyne vir die praktiese verwerkliking hiervan nie: Die Volkereg is vir'n geruime tyd reeds besig om kategorieë in dié verband te ontwikkel. Die Volkereg word daarmee die vernaamste hulpwetenskap van die aktuele politieke filosofie. Die uitdaging waarvoor die geskiedenis ons geplaas het, is duidelik: Die nasies moet hulle veelvoud en die eiesoortigheid van hulle historiese ervarings inbring in ' $n$ regsisteem wat as uitgangspunt die idee van die nasie het en die daarin geïmpliseerde norme van 'Selbstbehauptung und Anerkennung' (Willms). Die werklikheid dwing ons vandag tot die insig in die noodwendigheid en aktualiteit van die nasionale staatsidee.

\section{Literatuurverwysings}

BERMBACH, U \& KODALLE, KM (Hrsg) 1982. Furcht und Freiheit: Leviathan-Diskussion 300 Jahre nach Thomas Hobbes. Wiesbaden: Westdeutscher Verlag.

BITTERLI, U 1976. Die "Wilden" und die "Zivilisierten": Grundzüge einer Geistes- und Kulturgeschichte der europäisch-überseeischen Begegnung. München: $\mathrm{CH}$ Beck.

BLUMENBERG, H 1966. Die Legitimität der Neuzeit. Frankfurt: Suhrkamp.

HOEPFL, H 1982. The Christian polity of John Calvin. Cambridge: Cambridge University Press.

KESTING, H 1959. Geschichtsphilosophie und Weltbürgerkrieg. Heidelberg: Carl Winter.

KOSELLECK, R 1969 [1959]. Kritik und Krise: Ein Beitrag zur Pathogenese der bürgerlichen Welt. Frankfurt: Suhrkamp.

LÖWITH, K 1970 [1949]. Meaning in history. Chicago: University of Chicago Press.

LUBBE, H 1971. Theorie und Entscheidung. Freiburg: Rombach.

LÜBBE, H 1977. Geschichtsbegriff und Geschichtsinteresse. Basel: Schwabe.

LÜBBE, H 1978. Praxis der Philosophie, praktische Philosophie, Geschichtstheorie. Stuttgart: Reclam.

LUKÁCS, G 1970 [1922]. Geschichte und Klassenbewusstsein. Neuwied: Luchterhand.

MARQUARD, O 1973. Schwierigkeiten mit der Geschichtsphilosophie. Frankfurt: Suhrkamp.

MARQUARD, O 1979. Über die Unvermeidlichkeit von Üblichkeiten, in Oelmüller, $W$ (Hrsg), Normen und Geschichte. Paderborn: Ferdinand Schöningh.

MARQUARD, O 1981. Abschied vom Prinzipiellen. Stuttgart: Reclam.

MARQUARD, O 1981a. Vernunft als Grenzreaktion: Zur Verwandlung der Vernunft durch Theodizee, in Poser, $\mathrm{H}$ (Hrsg), Wandel des Vernunftbegriffs. Freiburg: Karl Alber.

MAURER, R 1982. Thesen zur politischen Theologie: Augustinische Tradition und heutige Probleme. ZThK 79/3, 349-373.

SCHMITT, C 1963 [1932]. Der Begriff des Politischen. Berlin: Duncker \& Humblot.

SCHMITT, C 1979. Die Tyrannei der Werte, in Jüngel, E, Schmitt, C \& Scheltz, S, Die Tyrannei der Werte. Hamburg: Lutherisches Verlagshaus. 
SCHMITT, C 1982 [1938]. Der Leviathan in der Staatslehre des Thomas Hobbes. Stuttgart: Klett-Cotta.

SWEEZY, P 1970. Theorie der kapitalistischen Entwicklung. Frankfurt: Suhrkamp.

WILLMS, B 1970. Die Antwort des Leviathan: Thomas Hobbes' politische Theorie. Berlin: Duncker \& Humblot.

WILLMS, B 1977. Selbstbehauptung und Anerkennung: Grundriss der politischen Dialektik. Wiesbaden: Westdeutscher Verlag.

WILLMS, B 1982. Antaios - oder die Lage der Philosophie ist die Lage der Nation, in Bolz, N W (Hrsg), Wer hat Angst vor der Philosophie? Eine Einführung in Philosophie. Paderborn: Ferdinand Schöningh.

WILLMS, B 1983. Kontingenz und Konkretion. Wilhelm von Ockham als Vorbereiter der neuzeitlichen Staatstheorie, in Schnur, R (Hrsg), Die Rolle des Juristen bei der Entstehung des modernen Staates. Berlin: Duncker \& Humblot. 